DOI 10.31558/2307-2318.2020.1.4

\title{
УДК: 504.03:658.5
}

Бєлобородова М.В., к.е.н., асистент кафедри туризму та економіки підприємства, НТУ «Дніпровська політехніка»

\section{УПРАВЛІННЯ ЕКОЛОГІЧНИМИ РИЗИКАМИ В СТРАТЕГІЇ РОЗВИТКУ ПРОМИСЛОВИХ ПІДПРИЕМСТВ}

В статті розглянуто місце та значення управління екологічними ризиками при формуванні та реалізації стратегії розвитку підприємств промисловості. Проаналізовано вітчизняні підходи до оцінювання екологічних ризиків, на основі чого виявлено, що наявні методики управління екологічними ризиками на промислових підприємств недостатньо враховують завдання стратегічного планування екологічної модернізації. Метою дослідження $є$ визначення особливостей екологічної стратегії розвитку промислових підприємств в рамках превентивного підходу до здійснення господарської діяльності із врахуванням управління екологічними ризиками. Із застосуванням методу теоретичного узагальнення та абстракції запропоновано класифікацію стратегій розвитку із врахуванням екологічних факторів діяльності промислових підприємств. Обгрунтовано значення оцінювання екологічних ризиків при стратегічному плануванні діяльності промислових підприємств із застосуванням логіко-аналітичних методів. Сформульовано основні вимоги до методики оцінювання екологічних ризиків, на основі чого наведено основні інструменти для аналізу і управління екологічними ризиками. Удосконалено наукові засади вибору екологічної стратегії розвитку промислових підприємств, що передбачає врахування наявних екологічних ризиків та екологічних умов проживання населення в містах їхнього розташування. Окрім цього, визначено основні групи чинників зміни підходу до господарювання в рамках екологічної модернізації, до яких віднесено жорсткість екологічних вимог 3 боку зовнішніх зацікавлених сторін, орієнтація на посилення екологічних конкурентних переваг, міжнародне та вітчизняне екологічне законодавство, освоєння інструментів формування і реалізації екологічної стратегії і політики, впровадження підходів до адаптації поточної діяльності відповідно до стратегічних і тактичних екологічних цілей. Проведені дослідження створюють підгрунтя для подальшого удосконалення методології оцінювання екологічних ризиків промислових підприємств, іiі реалізації в системі управління екологічними ризиками при здійсненні підприємствами власної економічної діяльності.

Ключові слова: екологічний ризик, стратегія розвитку, екологічна модернізація, інструменти екологічного управління, екологічна відповідальність, оцінка впливу на довкілля, екологічний аудит.

Табл. - 2, Літ. - 25

\section{Белобородова М.В. УПРАВЛЕНИЕ ЭКОЛОГИЧЕСКИМИ РИСКАМИ В СТРАТЕГИИ РАЗВИТИЯ ПРОМЫШЛЕННЫХ ПРЕДПРИЯТИЙ}

В статье рассматривается место и значение управления экологическими рисками при формировании и реализации стратегии развития предприятий промышленности. Проанализированы отечественные подходы к оценке экологических рисков, на основе чего выявлено, что существующие методики управления экологическими рисками на промышленных предприятиях недостаточно учитывают задачи стратегического планирования экологической модернизации. Целью исследования является определение особенностей экологической стратегии развития промышленных предприятий в рамках 
превентивного подхода к осуществлению хозяйственной деятельности с учетом управления экологическими рисками. Предложена классификация стратегий развития с учетом экологических факторов деятельности промышленных предприятий на основе применения метода теоретического обобщения и абстракции. Обосновано значение оценки экологических рисков при стратегическом планировании деятельности промышленных предприятий на основе логико-аналитических методов. Сформулированы основные требования к методике оценки экологических рисков, приведены основные инструменты для анализа и управления экологическими рисками. Усовершенствованы научные основы выбора экологической стратегии развития промышленных предприятий, предполагающие учет имеющихся экологических рисков и экологических условий проживания населения в местах их расположения. Кроме этого, определены основные группы факторов изменения подхода к хозяйствованию в рамках экологической модернизации, к которым отнесены ужесточение экологических требований со стороны внешних заинтересованных сторон, ориентация на усиление экологических конкурентных преимуществ, международное и отечественное экологическое законодательство, освоения инструментов формирования и реализации экологической стратегии и политики, внедрение подходов к адаптации текущей деятельности в соответствии со стратегическими и тактическими экологическими целями. Проведенные исследования создают основу для дальнейшего совершенствования методологии оценки экологических рисков промышленных предприятий, ее реализации в системе управления экологическими рисками при осуществлении предприятиями своей экономической деятельности.

Ключевые слова: экологический риск, стратегия развития, экологическая модернизация, инструменты экологического управления, экологическая ответственность, оценка воздействия на окружающую среду, экологический аудит.

\section{Bieloborodova M. ENVIRONMENTAL RISK MANAGEMENT IN THE DEVELOPMENT STRATEGY OF INDUSTRIAL ENTERPRISES}

The place and the role of an environmental risk management in the implementation of the industrial enterprise's development strategy is researched in the article. The national approaches to environmental risk assessment are analyzed. It is revealed that the available methods of environmental risk management at industrial enterprises do not sufficiently take into account the strategic planning objectives of environmental modernization. The aim of the research is to determine the features of the environmental development strategy of industrial enterprises in the framework of a preventive approach to economic activities. Using the method of theoretical generalization and abstraction, the classification of development strategies with consideration of environmental factors of activity of industrial enterprises is proposed. The importance of environmental risk assessment in strategic planning of industrial enterprises is substantiated by logic-analytical methods. The main requirements for the methodology of environmental risk assessment are formulated, the basic tools for the analysis and management of environmental risks are presented. The scientific principles of choosing an ecological development strategy of industrial enterprises were improved. The main groups of factors of changing approach to economic management within the framework of ecological modernization are identified, which include rigidity of ecological requirements from external stakeholders, orientation on strengthening of ecological competitive advantages, international and national ecological legislation, tools of formation and implementation of ecological strategy, implementation of approaches to adapt ongoing activities to strategic and tactical 
environmental. This research creates the basis for further improvement of the methodology of environmental risk assessment of industrial enterprises and its implementation in the system of environmental risk management of industrial enterprises.

Keywords: environmental risk, development strategy, environmental modernization, environmental management tools, environmental responsibility, environmental impact assessment, environmental audit.

Постановка проблеми. Незважаючи на досить складну екологічну ситуацію в Україні, сьогодні в галузі природокористування промислових підприємств основоположним стає превентивний підхід, який носить випереджальний характер і спрямований на пом'якшення негативного впливу на навколишнє середовище. Такий підхід грунтується на програмах розвитку галузей економіки регіону, екологічних інвестиціях в об'єкти природоохоронного значення, екологічній модернізації промислових підприємств. Одним із значущих компонентів зазначеного процесу $є$ управління екологічними ризиками, що дозволяє оцінити можливі загрози для підприємства і побудувати ефективну екологічну стратегію розвитку.

Аналіз останніх досліджень і публікацій. Проблеми стратегічного управління на засадах ефективного природокористування широко досліджені в роботах О. Амоші, Н. Андрєєвої, О. Садченко, О. Попової. Економіко-екологічні системи регіонального та локального рівнів в загальному вигляді досліджувались Г. Дейлі, О. Балуєвою, М. Пашкевич. Питання екологічної безпеки промислових підприємств розглядались такими вченими, як А. Бардась, А. Садекова, С. Харічкова.

Невирішені раніше питання. Однак, на нашу думку, на промислових підприємствах України управління екологічними ризиками переважно зосереджено на оцінці екологічного збитку з метою його грошового відшкодування (що де-факто $\epsilon$ санкцією), а не на усунення збитку, обмеження наслідків забруднення та запобігання подальшого негативного екологічного прояву. Формування екологічної способу господарювання, спрямованого на рішення природоохоронних та ресурсозберігаючих проблем із врахуванням наявних і потенціальних екологічних ризиків, обумовлює необхідність більш глибокого дослідження методологічних основ та підходів до формування екологічної стратегії розвитку промислового підприємства.

Мета статті. Основною метою даної статті $\epsilon$ визначення особливостей врахування екологічних ризиків при формуванні екологічної стратегії розвитку промислових підприємств.

Результати дослідження. Необхідно підкреслити, що в Україні все ще недостатньо нормативних методичних документів щодо способів визначення необхідних відновлювальних заходів і їх вартості відносно природокористування. Нечисленними $\epsilon$ нормативи оцінки ризику об'єктів впливу, вибору технічних методів і визначення рівня ліквідації наслідків забруднення. Крім того, в країні спостерігається недостатній кадровий потенціал і рівень професійних знань у сфері визначення розміру екологічної шкоди. При визначенні розміру шкоди компетентні органи керуються вже наявним збитком, практично не використовуючи методики теоретичного характеру. Продовжує використовуватись нормативний підхід до визначення розміру шкоди, заснований ще на радянських методологіях, як, наприклад, «Тимчасова типова методика оцінки економічного збитку, що завдається народному господарству забрудненням навколишнього середовища» (1983 p). У нормативному підході використовуються фіксовані цінові параметри в якості сурогату фактичних витрат на відновлення навколишнього середовища для розрахунку певного значення, яке вважається збитком. 
Розрахунок збитку таким чином надзвичайно спрощується і здійснюється без збору даних та економічних оцінок і обгрунтування незалежних експертів.

Однак, для забезпечення здійснення адекватних, своєчасних і спільних стратегій реагування підприємства на прояви екологічних ризиків, необхідно передбачати потенційні екологічні наслідки будь-якої діяльності, процесу або продукту на ранніх етапах планування. Мета полягає в створенні такого виробництва та інших економічних секторів, які б були прийнятні з економічної, соціальної та екологічної точки зору. Безумовно, в більшості випадків все ще буде необхідність в перехідному періоді, який потребуватиме здійснення контролю над забрудненням і проведення оздоровчих заходів. А тому, екологічне управління необхідно розглядати як складний процес запобігання і контролю, спрямований на приведення стратегій компаній у відповідність до екологічних вимог. Основними перепонами в процесі реалізації екологічної стратегії розвитку є:

- відсутність розроблених та впроваджених на практиці індивідуальних i корпоративних HR-проектів і програм, спрямованих на підвищення рівня корпоративної соціальної екологічної відповідальності та рівня екологічної свідомості, а також контролю ефективності реалізації таких проектів;

- недостатній контроль i нагляд 3 боку адміністративних органів у сфері відповідальності за екологічні правопорушення;

- відсутність достатнього фінансового стимулювання і ефективної реалізації економічних механізмів з боку держави щодо проектів, спрямованих на мінімізацію шкідливого впливу на навколишнє середовище і пов'язаних з екологічно безпечними технологіями вторинного і безвідходного виробництва, на реалізацію сучасних підходів до ресурсозбереження в процесі виробництва i на розробку i впровадження природоохоронних заходів на виробничих підприємствах;

- відсутність регулярного екологічного моніторингу та своєчасного формування екологічної звітності через ослабленого контролю з боку екологічних служб місцевого самоврядування;

- неефективна система управління екологічними ризиками на промислових об'єктах підвищеної небезпеки, що функціонують на території окремих муніципальних утворень, а також відсутність дієвих заходів щодо зниження цих ризиків і чітко регламентованих заходів по компенсації обумовлених ризиками втрат [1, С. 62].

Отже, аналіз існуючих в світовій практиці видів екологічних стратегій розвитку показав, що участь підприємства в житті соціуму може або жорстко регулюватися чинним комерційним, податковим, екологічним законодавством, або здійснюватися самостійно під впливом спеціально створених стимулів і пільг [2]. За першим сценарієм, державні інституції приймають повноправну участь у регулюванні екологічних стратегій розвитку, на рівні із іншими стейкхолдерами бізнесу (табл.1).

За іншим сценарієм, основною спонукальною силою для створення механізму стимулювання екологічних стратегій розвитку стають громадські ініціативи. Це дає змогу встановити діалог між громадою і підприємницькими структурами. Варто підкреслити, що для сучасних промислових підприємств, особливо таких, які належать до транснаціональних корпорацій і холдингів, характерним є поєднання кількох видів екологічних стратегій розвитку, використання найбільш сильних їх сторін.

Загалом, екологічна стратегія розвитку включає в себе філософію поведінки i напрями вибудовування діловим співтовариством, корпораціями та окремими підприємствами своєї діяльності з урахуванням екологічних пріоритетів. [11, С. 95]. 
Таблиця 1

Класифікація екологічних стратегій розвитку підприємств

\begin{tabular}{|c|c|c|}
\hline $\begin{array}{c}\text { Класифікаційні } \\
\text { ознаки }\end{array}$ & Види стратегій & Характерні риси \\
\hline \multirow{2}{*}{$\begin{array}{l}\text { За типом } \\
\text { стратегічних } \\
\text { переваг від } \\
\text { реалізації } \\
\text { (Д. Жардінс, } \\
\text { Ж.Дерій, } \\
\text { Т. Зосименко) }\end{array}$} & «Іміджева» & $\begin{array}{l}\text { Підприємства в ході вирішення екологічних проблем } \\
\text { створюють позитивний імідж, гудвіл. Пріоритетне завдання - } \\
\text { створення прибутку. }\end{array}$ \\
\hline & «Реальна» & $\begin{array}{l}\text { Підприємства при вирішенні екологічних проблем } \\
\text { отримують реальну економічну вигоду (зниження } \\
\text { собівартості за рахунок ресурсозберігаючих технологій, } \\
\text { повторне використання відходів). }\end{array}$ \\
\hline \multirow{3}{*}{$\begin{array}{l}\text { За напрямками } \\
\text { реалізації } \\
\text { (Глобальний } \\
\text { договір ООН, } \\
\text { О. Грішнова, } \\
\text { О. Брінцева, } \\
\text { А. Колот) }\end{array}$} & $\begin{array}{l}\text { Відповідальність } \\
\text { перед. } \\
\text { стейкхолдерами }\end{array}$ & $\begin{array}{l}\text { - захист та відновлення природного середовища визначені } \\
\text { стратегічними пріоритетами підприємства; } \\
\text { - діяльність в межах вимог екологічного законодавства; } \\
\text { - бізнес-культура, заснована на екологічних цінностях. }\end{array}$ \\
\hline & $\begin{array}{l}\text { Сировинний та } \\
\text { енергетичний } \\
\text { менеджмент }\end{array}$ & $\begin{array}{l}\text { - ефективне використання природних ресурсів; } \\
\text { - постійний аналіз екологічних досягнень та пошук нових } \\
\text { екологічних рішень; } \\
\text { - аналіз екологічних витрат, регулярне звітування. }\end{array}$ \\
\hline & $\begin{array}{l}\text { Дотримання } \\
\text { екологічних } \\
\text { зобов’язань }\end{array}$ & $\begin{array}{l}\text { - відповідальність перед громадою та іншими } \\
\text { стейкхолдерами за сучасну та майбутню діяльність; } \\
\text { - врахування громадської думки в межах соціального діалогу } \\
\text { при розробці та реалізації власних проектів; } \\
\text { - публічний доступ до інформації про вплив на довкілля, } \\
\text { звітування. }\end{array}$ \\
\hline \multirow{2}{*}{$\begin{array}{l}\text { За суб’єктним } \\
\text { складом } \\
\text { (В. Огородник, } \\
\text { А. Ореховський) }\end{array}$} & Корпоративна & $\begin{array}{l}\text { Глобальна відповідальності перед екологічною системою } \\
\text { планети. Стратегічна екологічна відповідальність в рамках } \\
\text { корпоративної культури всіх підприємств і організацій, які } \\
\text { входять до корпорації. }\end{array}$ \\
\hline & Індивідуальна & $\begin{array}{l}\text { Відповідальність кожної окремої як виробничої, так і } \\
\text { невиробничої організації, а також всіх їх стейкхолдерів, за } \\
\text { задовільний стан довкілля. }\end{array}$ \\
\hline
\end{tabular}

Примітка: складено на основі джерел [3, 4, 5, 6-10] 
Окрім цього, варто зауважити, що основними чинниками екологічної модернізації iз врахуванням екологічних ризиків промислового підприємства, $\epsilon$ жорсткість екологічних вимог з боку зовнішніх стейкхолдерів, посилення конкурентоспроможності підприємства за рахунок екологічних переваг, слідування нормам міжнародного та вітчизняного екологічного законодавства, застосування сучасних методів та методологій моніторингу і прогнозування можливих екологічних загроз і одночасно впровадження підходів до адаптації поточної діяльності відповідно до стратегічних і тактичних екологічних цілей.

Щодо проблеми управління екологічними ризиками, вітчизняними і зарубіжними вченими було розроблено ряд методик, які дозволяють оцінити рівень екологічної безпеки в розрізі різних аспектів. Так, методика оцінки екологічної безпеки, запропонована А. Дудкіним дозволяє проводити аналіз структури витрат на екологічну безпеку підприємства з точки зору їх обов'язковості і системності [12]. Більшою мірою методика може бути застосована в плануванні діяльності в області управління екологічними ризиками, ніж для їі безпосередньої оцінки. Методика оцінки екологічної безпеки, запропонована Г. Тульчинським, дозволяє порівняти промислові підприємства незалежно від виду їх діяльності [13]. В їі основі лежать показники, які характерні для будь-якого промислового підприємства. Оцінка складається з декількох етапів, серед яких визначення значень показників в балах із розрахунком вагових коефіцієнтів, аналіз динаміки показників у відсотках, визначення фактичного значення підсумкової суми балів. Д. Смоленніковим із метою кількісного оцінювання можливостей підприємства до впровадження заходів соціально-екологічної безпеки запропоновано інтегральний індекс можливостей підприємств теплоенергетики до впровадження соціальноекологічної відповідальності як середньозважене значення фінансових та нефінансових показників [14]. Безумовно позитивним в наведеній методиці $є$ кореляційний аналіз пропонованого показника із основними європейськими екологічними індексами.

Таким чином, продуманий механізм реалізації екологічної стратегії розвитку - це суттєвий інструмент запобігання порушення нормативних природоохоронних вимог, $\mathrm{i}$, як наслідок - виконання екологічного обов'язку промислових підприємств. Ряд вітчизняних науковців аналогічні функції покладають на такі інструменти управління екологічною діяльністю промислових підприємств, як екологічний аудит і оцінка впливу на довкілля (до 2017 року - екологічна експертиза) $[15,16]$, екологічну відповідальність як складову концепції соціальної відповідальності бізнесу.

Вважаємо доцільним розмежувати поняття екологічної відповідальності промислових підприємств, оцінки впливу на довкілля і екологічного аудиту за рядом ознак, а саме: об'єктно-суб'єктним складом, метою реалізації, характером публічності і обов'язковості, формами участі громадськості (табл. 2). Варто наголосити, що застосування перерахованих вище інструментів, дозволяють в значній мірі оптимізувати систему управління екологічними ризиками підприємств промисловості і врахувати подальші зміни як зовнішнього, так і внутрішнього оточення підприємств.

Оцінка екологічних ризиків промислових підприємств при формуванні їхньої екологічної стратегії розвитку здійснюється за допомогою прийомів і способів, в основі яких покладено загальнонаукові методи дослідження (аналіз, синтез, індукція, дедукція, аналогія, спостереження, експеримент і ін.). 
Таблиця 2

Основні інструменти управління екологічними ризиками

\begin{tabular}{|c|c|c|c|}
\hline 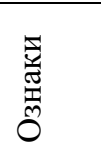 & $\begin{array}{c}\text { Екологічна відповідальність } \\
\text { промислових підприємств }\end{array}$ & Оцінка впливу на довкілля & Екологічний аудит \\
\hline 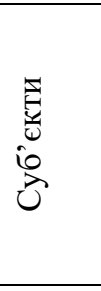 & $\begin{array}{c}\text { Суб’єкти господарювання, } \\
\text { місцева громада, органи } \\
\text { державної і місцевої влади, інші } \\
\text { стейкхолдери }\end{array}$ & $\begin{array}{c}\text { Суб’єкти господарювання, } \\
\text { органи державної влади, органи } \\
\text { місцевого самоврядування, } \\
\text { представники громадськості }\end{array}$ & $\begin{array}{c}\text { Органи виконавчої } \\
\text { влади, місцевого } \\
\text { самоврядування, } \\
\text { керівники чи власники } \\
\text { об'єктів екологічного } \\
\text { аудиту, екологічні } \\
\text { аудитори, громадськість } \\
\end{array}$ \\
\hline $\begin{array}{l}5 \\
0 \\
0\end{array}$ & $\begin{array}{c}\text { Система менеджменту, системи } \\
\text { контролю якості } \\
\text { навколишнього середовища в } \\
\text { зоні впливу підприємства, } \\
\text { стратегія підприємства, } \\
\text { виробничі процеси }\end{array}$ & $\begin{array}{c}\text { Планована господарська } \\
\text { діяльність, що включає } \\
\text { будівництво, реконструкцію, } \\
\text { технічне переоснащення, } \\
\text { розширення, } \\
\text { перепрофілювання, ліквідацію } \\
\text { (демонтаж) об’єктів }\end{array}$ & $\begin{array}{c}\text { Промислові } \\
\text { підприємства, їх } \\
\text { об’єднання, окремі } \\
\text { виробничі ділянки, } \\
\text { сировина, скиди, } \\
\text { відходи, система техніки } \\
\text { безпеки підприємства, } \\
\text { системи екологічного } \\
\text { управління }\end{array}$ \\
\hline 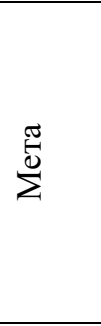 & $\begin{array}{c}\text { Екологізація промислової } \\
\text { діяльності, встановлення } \\
\text { еколого-економічної рівноваги } \\
\text { за рахунок соціального діалогу }\end{array}$ & $\begin{array}{c}\text { Забезпечення екологічної } \\
\text { безпеки, охорони довкілля, } \\
\text { раціонального } \\
\text { природокористування, у } \\
\text { процесі прийняття рішень про } \\
\text { провадження господарської } \\
\text { діяльності з урахуванням } \\
\text { екологічних ризиків } \\
\end{array}$ & $\begin{array}{c}\text { Забезпечення } \\
\text { додержання } \\
\text { законодавства про } \\
\text { охорону навколишнього } \\
\text { природного середовища } \\
\text { в процесі господарської } \\
\text { та іншої діяльності. }\end{array}$ \\
\hline 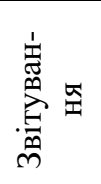 & $\begin{array}{c}\text { Соціальні звіти із розкриттям } \\
\text { екологічної інформації }\end{array}$ & $\begin{array}{c}\text { Звіт з оцінки впливу на } \\
\text { довкілля, Висновок з оцінки } \\
\text { впливу на довкілля }\end{array}$ & $\begin{array}{c}\text { Висновок екологічного } \\
\text { аудиту }\end{array}$ \\
\hline 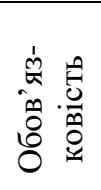 & Частково добровільна & Обов'язкова & $\begin{array}{c}\text { Добровільний/обов’язков } \\
\text { ий }\end{array}$ \\
\hline 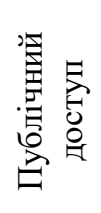 & Так & Так & $\begin{array}{c}\text { Так - при проведенні } \\
\text { зовнішнього } \\
\text { екологічного аудиту }\end{array}$ \\
\hline 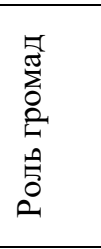 & $\begin{array}{c}\text { Участь у формуванні стратегії } \\
\text { розвитку промислового } \\
\text { підприємства, контроль, } \\
\text { встановлення соціального } \\
\text { діалогу }\end{array}$ & $\begin{array}{c}\text { Громадське обговорення, } \\
\text { внесення зауважень і } \\
\text { пропозицій, ініціювання після } \\
\text { проектного моніторингу, } \\
\text { оскарження «Висновку оцінки } \\
\text { впливу на довкілля» }\end{array}$ & $\begin{array}{c}\text { Ініціювання зовнішнього } \\
\text { аудиту }\end{array}$ \\
\hline
\end{tabular}

Примітка: складено на основі джерел [2, 17-22]

При цьому, важливо відзначити, що оцінка буде неповною, без визначення наявності взаємозв'язку між екологічною стратегією розвитку промислових підприємств 
і соціальними показниками розвитку місцевої громади, оскільки саме місцева громада може виступати як об'єктом реалізації екологічної стратегії, так і повноправним суб'єктом в процесі іiі формування на промисловому підприємстві. Система оцінювання повинна формувати загальне уявлення про наявні екологічні ризики, підтверджені результатами діяльності, соціальними (нефінансовими) звітами, статистичними даними, і служити інформаційною базою для подальшого аналізу, управління потенційними ризиками і прийняття обгрунтованих рішень. Варто наголосити, що згідно із науковими розробками Є. Сталінської [23], I. Потравного [24], О. Грішнової [5] методики комплексної оцінки екологічних ризиків та екологічної безпеки промислових підприємств повинні відповідати наступним вимогам:

- дозволяти оцінити екологічну діяльність промислових підприємств із урахуванням взаємозв'язку із соціальним розвитком громади в місті присутності досліджуваних підприємств;

- дозволяти здійснювати порівняльний аналіз промислових підприємств, а також виявляти кращі практики;

- забезпечувати можливість отримання деякого загального числового значення для оцінки досягнень групи промислових підприємств і виступати базою для побудови відповідних рейтингів;

- оцінка повинна базуватися на відносних показниках, у зв'язку із інтенсивними інфляційними процесами і специфічними особливостями галузевої діяльності;

- забезпечувати доступність отриманих значень для подальшої інтерпретації зацікавленими сторонами;

- формулювати пропозиції щодо розробки стратегії сталого розвитку і коригувати управлінські рішення з урахуванням екологічних аспектів.

При виборі і формуванні стратегії розвитку промислового підприємства для врахування інтересів всіх зацікавлених сторін необхідним вважаємо додержання принципу дуальності. Так, особливої актуальності набуває питання взаємодії між органами муніципальної влади i місцевого самоврядування та керівництвом промислових підприємств. В даний час інструментарій впливу муніципалітету на промислові та виробничі об'єкти, що функціонують на території муніципальних утворень, мізерний. Тому, показники результатів фінансово-господарської діяльності промислових і виробничих підприємств, що наводяться в офіційній звітності організацій і в засобах масової інформації, не об'єктивні і носять суто інформаційний характер [25, C. 31].

Висновки і перспективи подальших досліджень. В рамках проведеного дослідження встановлено, що врахування екологічних ризиків при виборі екологічної стратегії розвитку промислових підприємств дозволяє виявляти екологічно розумні альтернативи діяльності, прогнозувати можливі екологічні наслідки економічної діяльності в контексті існуючої екологічної ситуації на конкретній території. Застосування таких інструментів управління екологічними ризиками, як оцінка впливу на довкілля, внутрішній та зовнішній екологічний аудит дозволяють узгоджувати екологічні стандарти із економічними цілями промислових підприємств. Проведені дослідження створюють підгрунтя для подальшого удосконалення методології оцінювання екологічних ризиків промислових підприємств, іï реалізації в системі управління екологічними ризиками при здійсненні підприємствами власної економічної діяльності. 


\section{СПИСОК ВИКОРИСТАНИХ ДЖЕРЕЛ}

1. Шаповал В.М. Соціальна відповідальність бізнесу в структурі управління економікою: монографія / В.М. Шаповал. - Д.: Державний ВН3 «Національний гірничий університет», 2011. - $357 \mathrm{c}$.

2. Огородникова Н.Л. В.В. Инструменты механизма стимулирования корпоративной социальной ответственности в системе управления деятельностью предприятия / Н. Л. Огородникова // Вісник економічної науки України. — 2012. — № 1 (21). — С. 114-118. 3. Глобальний Договір ООН [Електронний ресурс] /Guide to Corporate Sustainability // United Nations Global compact - Режим доступу: www.unglobalcompact.org.

4. Berezhna M. Business environmental responsibility within the system of economic and social categories / V. Shapoval, M. Berezhna// Social Educational Project of Improving Knowledge in Economics. - JournalL'Association 1901 «SEPIKE»: Osthofen, Deutschland, Poitiers, France, 2014. - Ausgabe 6. - P.160-164.

5. Грішнова О. А. Екологічний вектор соціальної відповідальності / О. А. Грішнова, В. П. Думанська // Экономика и управление. - 2011. - № 3. - С. 32-41.

6. Des Jardins J. Corporate Environmental Responsibility / D.J. Jardins //Journal of Business Ethics - Vol. 17, no. 8 - 2013 - pp. 825-838.

7. Соціальна відповідальність: теорія і практика розвитку: монографія / А.М. Колот, О.А. Грішнова та ін..; за наук. ред. д-ра екон. наук, проф. А.М. Колота// - К.: КНЕУ, 2012. $501 \mathrm{c.}$

8. Дерій Ж.В. Екологічна компонента корпоративної соціальної відповідальності: світовий досвід та українські реаліі/Ж.В. Дерій, Т.I. Зосименко// Актуальні проблеми економіки, Випуск 11 - Національна академія управління, 2016 - С.278-290

9. Огородник В.В. Вплив екологічного компонента соціальної відповідальності на економіку країни/В.В. Огородник// Глобальні та національні проблеми економіки: електронне наукове видання, випуск 7// гол. ред. Стройко Т.В. - М.: Миколаївський національний університет ім. В.О. Сухомлинського, 2015. - С. 612-615. Режим доступу: http://global-national.in.ua/archive/7-2015/132.pdf

10. Ореховский А.И. Философия ответственности. Методологический, концептуальнотеоретический, правовой, аналитико-прогностический аспекты /А.И. Ореховский - М, «ТД Алгоритм», 2015 - 288 с.

11. Бережна М.В. Аналіз механізму державного регулювання екологічної відповідальності підприємств/ Бережна М.В. // Науковий вісник херсонського державного університету, Випуск 6, частина 2 / гол. ред. К.С. Шапошников - Х.: Херсонський державний університет, 2014. - С. 94-97.

12. Дудкін О.В. Організаційно-економічні основи розвитку соціальної відповідальності промислових підприємств : дис... канд. экон. наук // Суми. Сумський державний університет. 2011. С. 158-166.

13. Тульчинский Г.Л. Корпоративные социальные инвестиции и социальное партнерство: технологии и оценка эффективности. Учебное пособие / Г.Л. Тульчинский. - Санкт-Петербург: Изд-во Санкт-Петербургский филиал Нац. исслед. ун-та «Высшая школа экономики». 2012. - $236 \mathrm{c.}$

14. Смоленніков Д. О. Науково-методичний підхід до оцінки соціально-екологічної відповідальності підприємств теплоенергетики / Д. О. Смоленніков // Причорноморські економічні студії. - Одеса, 2016. - № 12-2. - С. 79-84.

15. Садеков А.А. Механизмы эколого-экономического управления предприятием [Текст]: монография/ А.А. Садеков// ДонГУЭТ им. М. Туган-Барановского.-Х.: ИД "ИНЖЭК", 2004.-224c. 
16. Басанцов I. В. Екологічний аудит в Україні: актуальність, проблемні питання та напрями удосконалення / I. В. Басанцов, О. С. Пантелейчук $1 / /$ Вісник Сумського державного університету. - Серія "Економіка". - 2009. - С. 25-30.

17. Закон України «Про оцінку впливу на довкілля» від 23.05.2017 р. /Верховна Рада України // [Електронний ресурс]. - Режим доступу: http://zakon0.rada.gov.ua/laws/show/2059-19

18. Закон України «Про охорону навколишнього природного середовища» редакція від 12.04.2018 р. /Верховна Рада України // [Електронний ресурс]. - Режим доступу: http://zakon2.rada.gov.ua/laws/show/1264-12

19. Закон України «Про стратегічну екологічну оцінку» від 20.04.2018 p. /Верховна Рада України// [Електронний ресурс]. - Режим доступу: http://zakon2.rada.gov.ua/laws/show/2354-19

20. Харічков С.К. Концептуальні засади управління ефективністю виробничої діяльності підприємства [Електронний ресурс] / С.К. Харічков, С.В. Бендас // Економіка: реалії часу. Науковий журнал. - 2014. - № 4 (14). - С. 11-19. - Режим доступу до журн.: http://economics.opu.ua/files/archive/2014/n4.html 6.

21. Колісник 3. Б. Вплив екологічної відповідальності на економічні результати діяльності лісопромислового сектора / 3. Б. Колісник // Науковий вісник НЛТУ України. - 2013. - Вип. 23.10. - С. 72-79. - Режим доступу: http://nbuv.gov.ua/UJRN/nvnltu_2013_23. 22. Закон України «Про екологічний аудит» від 24.06.2004 p. /Верховна Рада України// [Електронний ресурс]. - Режим доступу: http://zakon2.rada.gov.-ua/laws/show/2354-19

23. Сталинская Е.В. Оценка устойчивости развития металлургических предприятий / Е.В. Сталинская // Розвиток фінансових методів державного управління національною економікою: зб. наук. праць Донецького державного університету управління. Донецьк: ДонДУУ, 2012. - Т. XIII. - С. 363-370. - (Серія «Економіка»; вип. 218).

24. Потравный И.М., Сидорчук В.Л., Гусева О.В. Индикаторы качества окружающей среды в системе управления эколого-экономическими рисками // Экономика природопользования. 2001. № 3. С. $72-82$

25. Searcy C. Designing Corporate Sustainable Dvelopment Indicators: Reflection on a Process / C. Searcy, S. Karapetrovic, D. McCartney // Environmental Quality Management. 2009. - №11. - P. 31-42 